\title{
PERFORMING ORGANIZATION SEBUAH FORMAT PENGEMBANGAN ORGANISASIONAL (PO) DALAM ERA PERUBAHAN*)
}

\author{
Noor Arifin \\ Mahasiswa Program Pascasarjana Magister Sains \\ Universitas Gadjah Mada
}

\begin{abstract}
Abstrak
Ciri utama organisasi masa depan menurut Alfin Tofler adalah fleksibilitas, kreativitas, dan inovasi (enterpreneurship). Apa yang harus dilakukan oleh manajemen agar organisasi yang dipimpinnnya mampu mempertahankan eksistensinya dalam gelombang perubahan tersebut? Perubahan di masa depan akan semakin dahsyat dan radikal, menembus ke segala segi kehidupan. Para anggota dan pimpinan organisasional pada semua jajarannya akan dituntut kerja keras, dibarengi dengan menciptakan metode yang mutakhir, teknologi tinggi yang canggih, prosedur yang ringkas dan jelas, perumusan kebijaksanaan yang transparan dan selalu memberdayakan karyawan (employee empowerment).

Format PO masa depan yang bisa survive terhadap perubahan adalah Performing Organizational yang senantiasa menciptakan strategi kecocokan (fit) terhadap gejolak internal dan eksternal.

Indonesia dalam menghadapi krisis sekarang perlu mencari solusi terbaik dan menyiapkan untuk menghadapi perdagangan bebas dunia. Untuk jangka pendek Indonesia perlu perubahan transformasi organisasional (yang dilakukan secara radikal) dengan benar agar krisis dapat berlalu. Namun untuk jangka panjang perlu mengkombinasikan perubahan internal dan mengantisipasi perubahan eksternal dengan menerapkan konsep Performing Organizational. Konsep ini dapat dilaksanakan jika memang situasi dan kondisi memungkinkan, sehingga pendekatan yang dilakukan adalah contingency atau situasional.
\end{abstract}

\section{PENDAHULUAN}

Salah satu cirri dunia modern sekarang adalah munculnya uncertainty (ketidakpastian) dan perubahan cepat yang sangat massive, hal ini membuktikan kebenaran ungkapan bahwa "satu-satunya kepastian di dunia adalah ketidakpastian dan bahwa satu-satunya hal yang konstan di dunia adalah perubahan." Dikatakan demikian karena salah satu cirri utama dunia yang bagi orang awam sekalipun terlihat dengan jelas sekarang ini, yaitu terjadinya perubahan yang sangat cepat dan mencakup seluruh aspek kehidupan, yang akan memiliki dampak langsung maupun tak langsung terhadap kehidupan individual, berbagai kelompok masyarakat, semua jenis organisasi dan bahkan seluruh masyarakat bangsa. Perubahan ini menyangkut aspek ekonomis/bisnis, budaya, social, pertahanan/militer, informasi dll. baik yang berubah pada dimensi hardware-nya maupun dimensi software-nya, yang berarti bisa fisik maupun nonfisik, strukturnya ataupun instrumennya. Sehingga sekarang ini dapat dikatakan bahwa

*) Pernah diterbitkan pada Jurnal Siasat Bisnis edisi Th. IV Vol. 7, 1999 
dunia sama sekali menjadi baru dibanding sebelumnya. Tentu saja dunia baru yang memiliki trend baru itu perlu disikapi oleh para praktisi pengembangan organisasional, agar dalam menghadapi perubahan telah siap dengan konsep serta format yang adaptable dengan senantiasa menciptakan pemikiran yang inovatif namun sesuai dengan kondisi eksternal yang ada dan yang akan muncul. Oleh karena itu tulisan ini membahas bagaimana pengembangan organisasional (baik bergerak di bidang bisnis atau tidak) dalam mencari format di era perubahan yang terjadi secara berkelanjutan.

\section{PENGEMBANGAN MANAJEMEN ORGANISASIONAL}

Organisasi yang baik adalah organisasi yang melihat ke depan dan senantiasa mempersiapkan diri untuk itu. Organisasi harus melakukan forecast akan situasi lingkungan, agar lebih cepat tanggap dan dapat bersiap-siap sebelumnya terhadap perubahan lingkungan. Cara untuk menghadapi keadaan di atas adalah dengan mengembangkan dan melatih para manajer agar mereka mampu mengatasi berbagai masalah, tuntutan dan tantanga baru maupun melatih para karyawan agar mereka dapat mencapai potensinya secara penuh, karena semakin kompleks organisasi semakin membutuhkan peningkatan sumber daya manusianya baik kuantitas maupun kualitas.

Pengembangan organisasional adalah tanggung jawab pihak manajemen, sehingga area pengembangannya menyangkut pendekatan yang sistematik dan terencana untuk meningkatkan efektifitas organisasi. Hal ini dilakukan untuk mendesain organisasi dalam menghadapi perubahan yang sangat komplek di masa datang. Dalam uraian berikutnya penulis menggunakan istilah pengembangan organisasional yang di dalamnya sudah termasuk pengembangan manajerial.

\section{PERUBAHAN ORGANISASIONAL DAN PERAN MANAJER}

Perubahan yang terjadi pada lingkungan organisasional dewasa ini sangat berbeda dengan perubahan organisasional pada waktu yang lalu. Perubahan organisasional dahulu cenderung bersifat evolusioner dan berjalan secara stabil, namun perubahan organisasional sekarang dapat dikatakan cenderung bersifat radikal dan berjalan secara revolusioner.

Beberapa perubahan yang bersifat internal organisasional dapat dimulai dari pihak pimpinan organisasi atau orangnya, strukturnya, teknologinya, dan instrumen kebijakannya. Hal ini dilakukan untuk mengantisipasi perubahan eksternal yang begitu pesat namun penuh dengan ketidakpastian, khususnya yang dimunculkan oleh para pesaing, baik dari 
domestik nasional maupun korporasi multinasional. Di samping itu hal ini juga disebabkan adanya faktor pasar yang berubah terutama berkaitan dengan selera konsumen, serta gaya hidupnya.

Kondisi pasar, produk dan persaingan, membawa manajemen selalu dihadapkan pada perubahan. Oleh karena itu seorang manajer masa depan harus merupakan pakar-pakar pembaharuan, karena tugas para manajer di masa depan akan semakin dinamis dan penuh tantangan. Dengan demikian para manajer masa depan perlu bersikap proaktif dalam pengertian mampu mengantisipasi pola-pola perubahan dalam diri manusia itu sendiri, pasar, produk dan teknologi. Artinya dalam mewujudkan perubahan-perubahan haruslah terencana. Untuk itu ada tiga hal yang perlu dilakukan oleh para manajer dalam menghadapi perubahan:

1. Meningkatkan kemampuan organisasional yang mampu beradaptasi pada perubahan.

2. Menggunakan pendekatan kesisteman sebagai modal dinamis bagi berlangsungnya perubahan yang diinginkan, dan

3. Menyadari pentingnya transformasi dalam rangka perkembangan organisasional.

Dari kesemuanya itu peranan manajemen menjadi sangat penting bahkan sangat dominan, karena manajemen menjadi pendorong terjadinya perubahan, membantu meyakinkan para anggota organisasi bahwa perubahan tertentu diperlukan, serta menjadi agen pembaharu bagi organisasi yang dipimpinnya.

Salah satu tantangan yang dihadapi oleh berbagai organisasi dewasa ini adalah menampilkan manajemen yang efektif. Jika organisasi tidak mampu melakukan perubahan, tidak mustahil taruhannya adalah kelanjutan eksistensi organisasi yang bersangkutan. Setiap organisasi dihadapkan kepada berbagai sistem yang berada di luar kendali organisasi dan oleh karena itu organisasi harus mampu beradaptasi dengan berbagai kekuatan eksternal yang ada. Salah satu caranya adalah dengan melakukan perubahan internal organisasi supaya lebih efektif. Untuk meraih keberhasilan dalam mengelola perubahan, organisasi harus mengembangkan gaya dan kultur manajerial yang diarahkan pada peningkatan kemampuan menghadapi tantangan dan memanfaatkan peluang yang timbul. Artinya keputusan dalam menerapkan Pengembangan Organisasional (PO) harus diarahkan kepada perubahan perilaku manusia dan proses organisasional, hal ini dalam upaya menciptakan organisasional yang lebih adaptif dan luwes.

Pembaharuan organisasional merupakan hal yang sangat penting, karena tanpa pembaharuan organisasional, manajemen tidak mungkin mempertahankan keunggulannya. Dalam pada itu harus diakui bahwa pembaharuan sering dilihat dari sudut pandang yang dilematik. Di satu pi- 
hak, stabilitas ada kalanya dirasa perlu dipertahankan dan dipelihara karena tidak sedikit manajemen yang berpandangan bahwa perubahan tidak diperlukan karena dengan sistem yang berlaku, organisasi dapat meraih keberhasilan di masa lalu hingga sekarang. Di lain pihak, mempertahankan status quo sering menjadi sumber munculnya sifat menolak perubahan (resistance to change). Jadi tanpa kemauan dan kemampuan berubah, organisasi akan mengalami kesulitan dan tidak mampu menyesuaikan diri dengan tuntutan lingkungan.

\section{Tipe Perubahan}

Sebelum kita membahas lebih lanjut soal pengelolaan perubahan ada baiknya kita ketahui terlebih dahulu dua tipe perubahan yang terjadi, pertama, perubahan yang bersifat individual, yang terjadi pada masingmasing komponen organisasional secara individu dan terpisah-pihsak. Perubahan ini terjadi secara bertahap/evolutif yang seringkali berdampak pada sebagian kecil aspek-aspek organisasional, dan cara perubahan bertahap ini yang banyak diadopsi di Indonesia, kedua, perubahan yang bersifat strategic yaitu perubahan yang difokuskan pada organisasional secara keseluruhan, perubahan ini akan berdampak pada kinerja organisasional secara keseluruhan, sehingga perubahan ini sering pula disebut sebagai perubahan yang radikal. Variabel-variabel yang dirubah dalam kontek perubahan ini menyangkut beberapa hal yang sangat mendasar seperti budaya kerja, desain organisasi, prosedur-prosedur dan teknik-teknik pengambilan keputusan. Perubahan yang radikal merupakan cara melakukan perubahan dengan melakukan modifikasi struktur organisasional yang ada, proses manajemen yang ada, dan bahkan pula kehidupan social yang ada dalam organisasi tersebut.

Kendati perubahan bertahap merupakan cara yang paling banyak diadopsi, namun perubahan radikal pun sangat penting bila dilakukan sekali waktu, terutama jika saat kondisi mikro dan makro berada dalam keadaan "tidak sehat dan tidak pasti". Barangkali kondisi ekonomi dan politik Indonesia seperti saat ini adalah saat yang tepat dalam melakukan atau merencanakan perubahan yang strategic atau radikal.

Kemudian timbul permasalahan yang perlu diklarifikasi lebih lanjut, apakah perubahan stratejik dijamin akan memberikan hasil seperti yang diharapkan? Sebagai contoh adalah apa yang pernah dilakukan oleh seorang manajer perusahaan Grup terkenal di Indonesia. Ketika pada awal bergabung dengan perusahaan itu, manajer tersebut melakukan PHK di kantor pusat sebanyak 50\% (sekitar 250 orang) dari karyawan yang ada. Tentu saja langkah ini ditentang oleh banyak kalangan masyarakat luas terutama dari media massa. Namun alasan yang dikemukakan bahwa, perusahaan mustahil berjalan dengan sehat jika perusahaan dijalankan de- 
ngan cara tidak efisien. Lalu tujuh tahun kemudian pada awal tahun 1997, perusahaan mampu merekrut karyawan baru sebanyak 5000 orang. Hal ini menunjukkan bahwa apa yang dilakukan tujuh tahun sebelumnya adalah benar adanya.

\section{Perubahan Paternalistik}

Pada kondisi social yang paternalistic seperti di Indonesia posisi atasan sangat membantu dalam mengimplementasikan perubahan organisasi. Namun demikian keterlibatan karyawan (employee involvement) dalam proses perubahan sangat diperlukan. Hanya saja dalam mengkomunikasikan program perubahan masih merupakan hambatan besar, karena proses komunikasi transaksional dinamis antara keduanya belum dapat berjalan lancar atau belum menjadi budaya di Indonesia. Selama ini budaya komunikasi yang terjadi di Indonesia lebih merupakan proses komunikasi (top down). Dengan demikian proses perubahan sering diawali dari pihak manajemen puncak.

Menurut hasil survey yang dilakukan oleh Putti, 1989 di negaranegara Asean (termasuk Indonesia) bahwa prosentase perubahan organisasi $70 \%$-nya dimulai dari manajemen puncak, kemudian $17 \%$ konsultan internal, dan 3\% dimulai oleh konsultan eksternal. Jadi sebenarnya intervensi konsultan $\mathrm{PO}$ dapat dikatakan hanya sebagai pendorong perubahan (drive to change) bukan menjadi pelaku tunggal yang mengarahkan terjadinya perubahan (the one man show of change) (Yuniarto, 1998).

\section{MENGELOLA PERUBAHAN ORGANISASIONAL}

Perubahan yang terjadi akan berpengaruh pada organisasi secara langsung. Sehingga agar dapat berjalan dengan baik dan memberi dampak yang positif dalam organisasi perlu dikelola lebih baik. Menurut Daft (1992: 271-273, dalam Yuniarto, 1998), beberapa hal yang penting dalam mengelola perubahan adalah sebagai berikut:

a. Mendiagnosis kebutuhan perubahan, hal ini penting karena menyangkut apa yang harus dirubah, siapa yang terkena dampaknya, apa tujuan dan manfaatnya dari perubahan ini.

b. Menemukan kondisi yang tepat sehingga seluruh komponen organisasional siap untuk berubah, lalu menentukan kerangka waktu perubahan, apakah jangka panjang atau jangka pendek.

c. Mendisain kemudian mengimplementasi perubahan, sehingga hal ini perlu menggunakan model-model strategi serta teknik-teknik yang tepat untuk mengaplikasikan visi dan misi yang akan dicapai.

d. Membentuk tim-tim perubahan yang mandiri bebas dari intervensi manapun yang anggotanya bisa berasal dari luar organisasi (konsultan). 


\section{TREND PERUBAHAN}

Trend perubahan yang terjadi dalam organisasional dewasa ini sangat beragam diantaranya:

1. Perubahan dalam angkatan kerja, artinya angkatan kerja sekarang ini semakin beragam (diversity) sehingga kebijakan praktik SDM mestinya juga akan berubah.

2. Cenderung memanfaatkan teknologi informasi maju baik antar departemen internal maupun antar jaringan eksternal.

3. Perubahan struktur dan sistem, yang meliputi persoalan restrukturisasi (cenderung lebih flat yang mengakibatkan rentang kendali lebih lebar), downsizing, pembentukan tim, sistem pengendalian, sistem informasi, dan pengelompokan departemen.

4. Perubahan produk atau jasa, karena kebutuhan masyarakat menuntut organisasi untuk melakukan perubahan perbaikan yang terus-menerus (continuous improvement) terhadap produk/jasa yang ditawarkan, sehingga manajemen kualitas saat ini sangat menjadi perhatian.

5. Perubahan manusia (orang), manusia sebagai aktor perubahan, dia sangat berperan penting dalam sukses dan gagalnya organisasional. Perubahan ini menyangkut sikap, ketrampilan, ekspektasi, keyakinan, gaya, maupun perilaku. Artinya faktor sosiologis dan psikologis sangat berperan, dalam perencanaan dan implementasi perubahan manusia.

\section{AGENDA PENGEMBANGAN ORGANISASIONAL (PO) DI MASA DEPAN}

Sebagaimana dikemukakan di muka bahwa, $\mathrm{PO}$ dalam perubahan yang dinamis dan sangat cepat, menuntut organisasi untuk dapat menyesuaikan diri dengan lingkungannya. Hal ini dapat dilakukan dengan menggunakan pendekatan-pendekatan, model-model strategi, sistem, dan teknik-teknik sebagai modal dinamis dalam melakukan perubahan yang diinginkan. Keberhasilan penerapan pendekatan tersebut dapat memberikan kemungkinan organisasi dapat mencapai tingkat kinerja (performance) yang dikehendaki dengan tingkat nilai yang lebih disbanding organisasi lain. Untuk itu hendaknya para manajer dan praktisi (PO (konsultan) perlu lebih mengenali berbagai kecenderungan ke arah mana PO akan bergerak di masa depan. Kecenderungan dimaksud akan menampakkan dirinya dalam berbagai bentuk, baik dalam arti pendekatan, sistem yang dapat diterapkan secara makro, sistem manajemen sumber daya manusia maupun perubahan pada tingkat individual seperti berikut:

口 Transformasi Organisasi (TO)

Merupakan bentuk strategi perubahan yang bersifat revolusioner dalam PO. Karena perubahan ini meliputi: struktur organisasi, proses manajemen, dan kultur organisasi. Ini dilakukan jika terjadi perubahan 
yang drastic dan mendadak, strategi yang dipertaruhkan adalah kelangsungan hidup organisasional. Bentuk-bentuknya bisa berupa penggabungan organisasi dengan organisasi/perusahaan lain, misalnya: merger, akuisisi, PHK besar-besaran dll. TO sering pula berakibat pada restrukturisasi.

- Visi Bersama

Untuk dapat berhasil pada masa yang akan datang antara manajer dan bawahan harus memiliki visi bersama dengan jelas tentang cira dan profil organisasi yang ideal yang dipimpinnya dalam menghadapi berbagai perkembangan, tantangan serta situasi ketidakpastian. Sehingga visi bersama ini akan memberi motivasi untuk berkarya bersama menuju tujuan bersama.

- Inovasi

Untuk meningkatkan efektifitas dan produktivitasnya, maka organisasi memerlukan cara berpikir dan bertindak yang inovatif baik inovatif dalam penciptaan produk baru (barang dan jasa), struktur baru, hubungan baru, bahkan juga kultur yang baru.

a Iklim saling Mempercayai

Hal ini harus terjadi dalam hubungan dan interaksi antara individu-individu, antar tim, antar kelompok dan antar kesatuan kerja dalam seluruh jajaran organisasi. Tidak saling curiga-mencurigai dan saling menjegal antar sesama.

- Pemberdayaan

Karyawan sebagai anggota organisasi selain memenuhi tanggungjawabnya juga hendaknya dalam melakukan pekerjaan harus "berdaya" artinya diperlakukan sebagai orang yang memiliki tanggung jawab yang besar, diajak dalam proses pengambilan keputusan, kemudian diberikan kebebasan bertindak dalam menentukan segala sesuatu yang menyangkut pekerjaannya, dan akhirnya dia diberi kesempatan untuk mengembangkan potensi yang dimiliki sehingga potensi itu menjadi kemampuan operasional yang efektif.

口 Dampak Perubahan Kultur

Salah satu sasaran kegiatan PO adalah mengubah kultur suatu organisasi yang kondusif. Oleh karena itu supaya tidak terjadi "cultural shock" dari seluruh anggota organisasional perlu diantisipasi sebelumnya, sehingga tidak mempengaruhi tugas yang diemban.

- Penggunaan Berbagai Sumber

Supaya tidak terjadi kelangkaan maka perlu digunakan berbagai sumber daya namun tetap dengan memperhatikan efisiensi.

- Masalah Sentralisasi dan Desentralisasi

Dalam melakukan kebijaksanaan organisasi adakalanya dilakukan secara terpusat atau sentralisasi dan melalui pendelegasian wewenang, 
otonomi dan pemberdayaan (desentralisasi). Tentu saja ini dapat dilakukan akan tergantung pada banyak faktor. Maka faktor-faktor itulah yang perlu dicermati oleh praktisi PO nantinya.

a Penyelesaian Konflik

Perlu kemampuan menangani konflik antar anggota organisasi yang bersifat fungsional tidak disfungsional, sehingga perbedaan bukan menjadi masalah dan hambatan, namun menjadi sinergi dalam PO.

- Kerja Sama Antar Organisasi

Ini dapat dilakukan melalui pembentukan "jaringan" (networking) kemitraan, sehingga dalam melakukan tanggungjawabnya dapat berjalan dengan baik.

- Penggabungan Fungsi Lini dan Staf

Wujudnya adalah dengan kecenderungan untuk mengurangi lapisan manajemen dengan struktur organisasi yang lebih datar, lebih ciut besaran organisasionalnya dan mengurangi jumlah tenaga kerja, sehingga timbul gejala untuk menggabungkan fungsi-fungsi lini dan staf dalam organisasional.

a Pluralisme

Adanya heterogenitas antar anggota yang sangat plural di satu sisi, baik plural ditinjau dari sisi usia, jenis kelamin (gender), latar belakang social, pendidikan, asal-usul daerah, kepribadian dan sistem nilai yang dianut. Di sisi lain plural dalam menghadapi pesaing karena batas-batas negara sudah mulai hilang sehingga perusahaan dunia mulai berdatangan. Maka perlu menuntut integrasi sistem nilai dan ketrampilan yang perlu dimanfaatkan.

a Nilai Intrinsik

Banyak dari kalangan teoritisi perilaku organisasional sepakat bahwa motivasi intrinsic (dorongan yang mengarah pada segi bathiniyah manusia, misalnya: penghargaan, pujian, promosi, dll). lebih besar peranannya dalam kehidupan para organisasi pada umumnya daripada motivasi ekstrinsik (misalnya : gaji, bonus, dII), terutama dalam mengatasi berbagai stress dalam pekerjaan seseorang.

- Integrasi "Mutu Hidup Kekaryaan (QWL)" dengan Produktivitas

Peningkatan mutu hidup kekaryaan merupakan hal yang sangat penting, hal ini bisa dilakukan melalui penyeliaan yang simpatik, pekerjaan yang menarik dan menantang, dukungan manajemen puncak, iklim saling mempercayai dan kondisi fisik pekerjaan yang kondusif bagi peningkatan produktivitas. Manajemen sangat berkepentingan dalam hal ini.

- Efek Cara Berfikir

Manusia adalah makhluk berfikir. la memiliki akal dan daya nalar. Karena itu dia manusia memiliki kemampuan untuk berfikir analitik 
meskipun pada tingkat yang berbeda-beda dari individu ke individu yang lain. Berbagai tingkat kemampuan intelektual yang demikian mendorong manusia sebagai anggota organisasional mempertanyakan kultur dan sistem nilai yang dianut oleh organisasi, apakah kultur organisasi tersebut senada dengan kultur dan sistem nilai pribadi orang yang bersangkutan. Kemudian penyesuaian apa yang perlu dilakukan agar perilaku anggota sesuai dengan perilaku organisasional. Hal tersebut penting bagi manajemen dan praktisi PO agar dalam diri anggota organisasional dapat ditumbuhkan cara berfikir positif (positiv thinking) dalam hal harus terjadinya perubahan kultur organisasi dan dalam mengembangkan kultur baru di masa depan sesuai dengan tuntutan zaman.

- Program Kesehatan dan Kebugaran

"Men sana in corpore sano" dalam tubuh yang sehat terdapat jiwa yang sehat, jika karyawan kelihatan sehat dan bugar, baik fisik dan mental psikologisnya akan mampu menampilkan kinerja yang prima, produktivitas yang tinggi dan tingkat kemangkiran yang rendah. Sehingga stress yang diderita karyawan dapat ditekan jika diberikan sarana untuk olah raga yang mencukupi dan konseling bagi karyawan, karena jika seseorang memiliki tingkat kesehatan yang prima, diharapkan segala sesuatu yang menyangkut tugas hidup dan tanggung jawabnya akan berjalan dengan lancar, tepat waktu serta dengan kualitas baik memiliki performance yang tinggi. Jadi di sini kesehatan sangat erat berkaitan dengan kinerja organisasi yang tinggi.

口 Interdependensi

Organisasi di masa depan akan semakin komplek, meskipun tidak selalu dalam arti strukturnya. Bahkan menciptakan struktur yang lebih "datar" dan lebih sederhana akan merupakan tantangan tersendiri bagi manajemen. Dengan adanya tingkat kompleksitas yang tinggi tersebut, maka perlu usaha untuk saling bekerja sama, berinteraksi dan interdependensi makin tinggi. Menciptakan tim yang solid dengan penuh kebersamaan dan saling memiliki satu sama lain.

\section{FORMAT PO MASA DEPAN YANG VALUABLE DALAM PERUBAHAN}

Ciri utama organisasi masa depan menurut Alfin Toffler adalah fleksibilitas, kreativitas, dan inovasi (enterprenuership). Lalu pertanyaan yang timbul, adalah apa yang harus dilakukan oleh manajemen agar organisasi yang dipimpinnya mampu mempertahankan eksistensinya dalam gelombang perubahan tersebut? Jawabannya dapat disebutkan bahwa organisasi harus mau menjadikan 3 faktor yang telah dikemukakan oleh Alfin sebagai sarana dan proses untuk mencapai tujuan secara konsisten 
dengan komitmen yang tinggi. Namun untuk melakukan hal itu, organisasi perlu mengubah format strateginya. Dalam melakukan PO perlu diciptakan strategi yang baru dalam menghadapi tantangan di masa depan sehingga akan senantiasa proaktif terhadap perubahan Performing Organisation adalah sebuah konsep yang memiliki pandangan bahwa organisasi pada decade dewasa ini harus berada pada posisi unggul dan berkinerja tinggi. Hal yang penting di sini adalah "unggul" dan "berkinerja tinggi". Untuk mencapai dua posisi tersebut, yang harus dilakukan oleh organisasi/perusahaan bisnis adalah: Strategy, bagaimana organisasi akan efektif dan efisien mencapai tujuannya dapat dilakukan dengan cara:

a. Senantiasa meningkatkan total kualitas dan produktifitas produk atau jasanya, yang diarahkan pada kepuasan internal customer dan external customer. Internal customer kita ketahui adalah seluruh anggota organisasi dari segala tingkatan yang ada dalam organisasi. Sementara external customer adalah customer yang berada di luar organisasi atau pasar (individu, masyarakat dan lembaga yang lain). Usaha untuk mengarahkan demi kepuasan terhadap customeri disebut "customer focus". Kemudian dilanjutkan dengan melakukan perbaikan kualitas secara terus-menerus (continuous improvement), selalu mempertahankan kualitas produk atau jasanya atas dasar komitmen dari seluruh anggota organisasi, sehingga komitmen tersebut akan menjadikan kualitas total sebagai budaya organisasi (corporate culture).

b. Senantiasa meningkatkan kemampuan manajerial (managerial skill) terutama tentang kepemimpinan yang menunjukkan perhatian maksimum baik terhadap orang/karyawan (empowerment) maupun terhadap produksi.

c. Memiliki sistem kinerja tinggi (high performing system) yang merupakan hasil keputusan dari telaah dan diagnosis organisasi, yang kemudian ditindaklanjuti melalui pendekatan rekayasa yang radikal dan menyeluruh (reengineering) untuk mencapai kinerja yang lebih baik.

Culture, menciptakan norma, aturan dan prinsip yang mendasari serta memberi petunjuk perilaku organisasional sehari-hari dengan budaya kerja yang kondusif. Sehingga proses hubungan antara atasan dan bawahan didasari atas tipe kepemimpinan transformasional yang dapat membawa keberhasilan dalam perubahan.

Management Process, bagaimana seorang manajer dapat menggunakan sumber daya manusia dan sumber daya material sehingga bisa membawa ke arah keberhasilan strategi organisasi yang telah ditetapkan. Karena manajemen masa depan masuk pada gelombang ketiga yakni berada tahap "dunia bisnis" setelah tahap pertama (pertanian) dan tahap kedua (era industri) berlalu. Ciri-ciri manajemen pada gelombang ketiga ini: - Organisasinya berbentuk pada pola networking (jaringan) tidak hirarki. 
- Gayanya menekankan kunci flexibility (luwes) bukan terstruktur.

- Strukturnya bersifat interdependensi bukan kemandirian.

- Fokusnya pada individual bukan institusi.

- $\quad$ Output nya menuju ke penciptaan pasar bukan pangsa pasar.

- $\quad$ Sumber kekuatannya adalah perubahan bukan stabilitas (status quo).

- Sumber dayanya adalah informasi bukan uang.

- Motivasinya adalah membangun bukan penyelesaian tugas.

- Keunggulannya adalah perbedaan yang bermakna (synergy) bukan kesamaan yang lebih besar.

- Cakupannya adalah multilokal bukan multinasional, dan

- Cara pandangnya adalah bersifat strategis bukan bersifat taktis.

\section{TANTANGAN PERFORMING ORGANIZATION}

Tantangan untuk melaksanakan Performing Organization akan kita buktikan kebenarannya, namun sekali lagi Performing Organization bukan satu-satunya cara jitu yang menjamin akan membawa keberhasilan mutlak, namun hal ini hanya salah satu cara yang dapat kita perhatikan dalam menanggapi perubahan serta kesiapan organisasi di saat persaingan yang semakin kompetitif. Karena berhasil tidaknya sebuah cara yang digunakan akan sangat tergantung kepada pelaku dan kondisi yang menyertainya.

Konsep ini cukup idealis, namun bisa diterapkan kapan saja dan oleh siapa saja yang merasa perlu mempergunakannya dalam membenahi organisasi yang ingin perubahan, terutama terhadap organisasi yang berskala nasional dan multi nasional. Kenapa Performing organization harus dilaksanakan:

1. Telah terjadinya perubahan pada tingkat regional dan global terutama perkembangan baru di bidang ekonomi dan perdagangan, misalnya; di kawasan Asean diciptakan AFTA. Di Asia Pasific terdapat APEC. Di Eropa sudah lama terdapat MEE. Kemudian Amerika, Kanada, dan Mexiko bergabung alam NAFTA. Di Asia Selatan ada SAEC. Di Afrika ada Arican Financial Community. Di Brasillia, Argentina, Paraguay dan Uruguay bergabung dalam MERCOSUR. Bolivia, Kolombia, Ekuador, Peru dan Venezuela membentuk ANDEAN PACT. Di Amerika Tengah terdapat Central American Economic Union. Lalu GATT oleh PBB ditingkatkan fungsinya dengan mana WTO, dan masih banyak lagi. Yang kesemuanya lambat atau cepat akan menjadi pesaing langsung maupun tak langsung dengan organisasi bisnis kita. Mereka merupakan kebanyakan negara menganut sistem modern dengan negara manapun. Dengan konsep dan strategi yang matang mereka akan secara besar-besaran menanamkan investasinya ke negara-negara yang 
dipandang sebagai sasaran pasar potensial. Dengan demikian mereka akan menawarkan produk dan jasanya yang prosesnya melalui teknologi canggih dengan kualitas tinggi akan diluncurkan ke berbagai negara termasuk Indonesia.

2. Di sisi internal Indonesia sendiri sudah terjadi tuntutan perubahan dari berbagai pihak apakah berasal dari anggota organisasi sendiri atau dari luar organisasi. Mereka mulai memiliki sense of bargaining poweri kepada manajemen, menuntut kepada perbaikan di segala bidang dalam organisasi. Tidak hanya segi ekonomis saja yang dituntut namun segi hukum, keamanan dan kesejahteraan mereka harapkan, sehingga memang tidak dapat ditawar-tawar lagi oleh organisasi untuk berubah. Selanjutnya sisi eksternal tuntutan masyarakat terhadap selera dan kebutuhan makin tinggi karena sudah mulai ada kebebasan untuk memilih produk dan jasa kesukaannya, yang tidak hanya di dalam negeri saja namun di luar negeripun dapat dibeli dengan mudah melalui teknologi internet mail (E-mail) misalnya, dalam melakukan transaksi. Hal ini dapat diakses kapan-kapan saja dan dimana saja tanpa ada hambatan.

3. Hal lain adalah tingkat pendidikan masyarakat sudah semakin merata dan familiar terhadap memanfaatkan teknologi tinggi. Hal ini mau tidak mau akan menjadi tuntutan organisasi bisnis dan non bisnis menawarkan prduknya dengan kemudahan teknologi. Oleh karena ini organisasi tidak cukup dengan mengandalkan strategi tradisonalnya saja namun saja akan lebih lengkap dan bahkan jika perlu diganti dengan strategi yang modern.

Tantangan jika performing organization tidak dilaksanakan, maka perlu penyesuaian terlebih dahulu dengan mempelajari kemungkinan kemampuan kondisi obyektif organisasinya. Artinya keberadaan Performing Organization ini minimal perlu diaplikasikan untuk mencapai tujuan optimalisasi dalam jangka panjang, tidak sekedar jangka pendek, sehingga setiap organisasi harus berfikir dengan melihat perubahan yang menjadi tantangan selanjutnya. Bukan hal yang mustahil jika para pelaku ekonomi global sebagaimana disebutkan di atas sudah masuk ke Indonesia, akan merupakan bumerang dan pesaing dahsyat pasar kita, mereka akan datang dengan beribu macam jenis bisnis dengan produk kualitas prima yang sudah dibuktikan dengan penghargaan ISO-nya dan kita tampaknya hanya bisa bertahan dalam masa yang tidak terlalu lama, dengan demikian posisi di sini hanya sementara, karena kita kalah bersaing tidak dapat mempertahankan keberadaan organisasi bisnis di negeri sendiri, sementara kita juga tidak mau menjadi status organisasi follower (mudah-mudahan tidak). 


\section{MENYIAPKAN KONDISI INDONESIA}

Pada saat Indonesia menyepakati perdaganan bebas di ASEAN (AFTA), bersama itu pula terjadi krisis moneter (walaupun seluruh ASEAN juga terkena krisis) yang hampir meruntuhkan sendi perekonomian. Artinya persiapan yang kita hadapi akan menjadi dua tahap, pertama kita perlu mengatasi krisis terlebih dahulu kemudian baru menyiapkannya untuk menyongsong AFTA. Namun persoalannya adalah kapan krisis berlalu? Dan berapa lama lagi, apakah setelah krisis selesai akan pulih (recovery) kembali seperti sediakala, dan langsung menjadi kuat ekonominya sehingga julukan the miracle economic dengan pertumbuhan $7 \%$ pertahun dapat kita peroleh kembali. Memang semuanya perlu proses dan waktu, serta melalui penanganan secara benar. Karena krisis yang menyerang dasar fundamen kita sekarang ini, sudah menjalar ke krisis ekonomi, social politik (kepercayaan), kemudian yang parah lagi adalah hubungan internasional kita lost of confidence, sehingga mengakibatkan financial flow ke Indonesia tidak lancar karena terjadi komplikasi politik, jadi kita ini mengalami krisis total (M. Sadli, dalam diskusi). Maka menurut penulis, untuk mempersiapkan kondisi Indonesia perlu dilakukan dua model untuk mengantisipasi perubahan yakni:

1. Melaksanakan perubahan transactional factor yaitu model perubahan yang dilakukan untuk mengatasi respon dari faktor internal, yang meliputi faktor: struktur, sistem, manajemen praktik dan iklim organisasi.

2. Perubahan transactional factor yaitu model yang dipilih sebagai respon terhadap lingkungan eksternal yang terjadi, dan secara langsung faktor ini mempengaruhi misi dan strategi, kepemimpinan organisasi, serta budaya organisasi.

Faktor-faktor dari dua model tersebut di atas terjawab jika kita bisa menerapkan performing organization seperti yang telah dijelaskan di depan. Untuk itu format PO masa depan yang bisa survive terhadap perubahan di Indonesia, menurut penulis adalah performing organization yang senantiasa menjaga fit (kesesuaian) terhadap aspek perubahan internal dan eksternal (semoga).

\section{KESIMPULAN}

Perubahan di masa depan akan terjadi semakin dahsyat dan radikal, menembus ke segala segi kehidupan. Para anggota organisasional pada semua jajarannya tetap akan dituntut kerja keras, dibarengi dengan menciptakan metode yang mutakhir, teknologi tinggi yang canggih, prosedur yang ringkas dan jelas, perumusan kebijaksanaan yang transparan dan yang penting adalah memperdayakan karyawan (empowementi). 
Format PO masa depan yang bisa survive dalam era perubahan adalah performing organizational yang senantiasa menjaga fit terhadap gejolak internal dan eksternal.

Indonesia dalam menghadapi krisis sekarang perlu mencari solusi terbaik dan menyiapkan model jitu dalam menghadapi perdagangan bebas dunia. Untuk jangka pendek, Indonesia perlu perubahan yang transformatif (yaitu perubahan organisasional yang dilakukan secara radikal) dengan benar agar supaya krisis dapat berlalu. Namun untuk usaha jangka panjang, perlunya mengkombinasikan perubahan internal dan mengantisipasi perubahan eksternal dengan menerapkan konsep performing organization. Konsep penawaran ini dapat dilaksanakan jika memang situasi dan kondisi memungkinkan, sehingga pendekatan yang dapat diterapkan di Indonesia adalah dengan contingency opproachi atau pendekatan situasional.

\section{DAFTAR PUSTAKA}

Burke Warner, W and Litwin H. George, (1992), A Causal Modek of Organizational Performance and Change, Journal of Management, Vol. 18, No. 3, 523-545.

Harvey Don F. and Brown Donald R, (1996), An Experiential Approach To Organizational Development, Fifth Edition, New Jersey: PrenticeHall Inc.

Luthans F. (1996), Organizational Behavior, Seventh Edition, Singapore: McGraw-Hill International Editions.

Palmer lan and Dunford Richard, (1996), Conflicting Uses of metaphors: Reconceptualizing Their Use In The Field Of Organizational Change, Academy of Management Review, Vol. 21. 691-717.

Reksohadiprodjo, S. dan Handoko, Hani, (1992), Organisasi Perusahaan: Teori, Struktur, dan Perilaku, Edisi Kedua, BPFE UGM, Yogyakarta.

Robbin P. Stephen, (1996), Organizational Behavior: Ceoncept, Controversies, Applications, Seventh Edition, Ney Jersey PrenticeHall, Inc A Simon \& Schuster Company.

Siagaan P. Sondang, (1995), Teori Pengembangan Organisasi, Jakarta, Bumi Aksara, Sinar Grafika Offset.

Staw Barry M. (1992), Psychological Dimension of Organizational Behavior, New York Mcmillan Publising Company.

Yuniarto E. Andriaono, (1998), Perubahan Organisasional: Konsep dan Tantangan, Wahana, Volume I, No. Agustus 21-32. 